\title{
Аналіз наукових положень ресурсних концепцій в економічній теорії і теорії стратегічного управління
}

\author{
Анатолій Лойшин ${ }^{1 \text { А }}$ \\ А Національний університет оборони України імені Івана Черняховського, пр-т Повітрофлотський, 28, м. Київ, 03049, Україна
}

Received: May 1, 2021 | Revised: June 10, 2021 | Accepted: June 30, 2021

DOI: $10.33445 /$ sds.2021.11.3.4

\begin{abstract}
Анотація
У статті узагальнено аргументи та контраргументи в межах наукової дискусії з питання розроблення сучасної концепції ресурсного забезпечення сектору безпеки і оборони України. Метою дослідження $\epsilon$ аналіз економічної теорії і теорії стратегічного управління стосовно наявності теоретичних положень про трансформацію змісту економічної категорії "ресурси" та ресурсних концепцій для розуміння їх наукового змісту і передумов розвитку для розроблення сучасної концепції ресурсного забезпечення сектору безпеки і оборони України. На підставі систематизації літературних джерел та підходів до вирішення проблеми ресурсного забезпечення сектору безпеки та оборони України визначено, що в економічній теорії і теорії стратегічного управління наявні підходи, що можуть бути використані у подальших дослідженнях предметної сфери. Актуальність вирішення цієї наукової проблеми підтверджують заходи, ініційовані керівництвом держави відповідно до концептуальних документів з державного управління та оборонного планування. Предметну площину у статті досліджено в такій логічній послідовності: проаналізовано економічну теорію, потім - теорію стратегічного управління, сформульовано висновки. Методичним інструментарієм проведеного дослідження стали аналіз, синтез, декомпозиція, історичний метод. У дослідженні наведено результати емпіричного аналізу економічної теорії і теорії стратегічного управління, а саме відзначено, що в ході розроблення сучасної концепції ресурсного забезпечення сектору безпеки та оборони необхідно враховувати головні категорії ресурсної концепції: ресурси, здібності, компетентності, організаційну рутину. У дослідженні емпірично підтверджено і теоретично доведено, що питання наукового дослідження ресурсів як економічної категорії та операцій з ними $\epsilon$ актуальним з часів Арістотеля, що підтверджується постійним пошуком механізмів оптимального їх використання з урахуванням фактора обмеженості. Результати проведеного дослідження можуть бути корисними для науковців та управлінців, які вивчають проблематикою всебічного забезпечення у сфері сектору безпеки та оборони України.
\end{abstract}

Ключові слова: ресурси, ресурсна концепція, економічна теорія, стратегічне управління.

\section{Постановка проблеми}

Станом на цей час, Україна восьмий рік поспіль протистоїть збройній агресії з боку Російської Федерації, яка маніпулюючи населенням, яке проживає на тимчасово окупованих територіях, намагається висвітлювати події не як свої загарбницькі дії, а як громадянську війну в Україні.

На початку збройної агресії у 2014 році
Збройні Сили України перебували у вкрай важкому стані. Зрадницька позиція попереднього керівництва держави призвела до руйнації сектору безпеки та оборони України: значного скорочення структурних підрозділів, їх передислокації зі стратегічно важливих районів та фінансування за залишковим принципом.

\footnotetext{
1 доктор філософії, старший викладач кафедри економіки та фінансового забезпечення, e-mail: aloishyn@gmail.com, ORCID: 0000-0003-2769-9336
} 
Водночас Україна змогла мобілізувати усі наявні резерви для боротьби з ворогом, що підтверджено швидкими реформами у сфері безпеки й оборони. Уряд виділив значні фінансові та інші ресурси для приведення Збройних Сил України та інших військових формувань, передбачених законодавством України до боєздатного рівня. Стрімкому зростанню рівня боєздатності, сприяли залученість усього Українського народу, волонтерський рух, робота місцевих адміністрацій та значні фінансові внески бізнесу.

Так, військовослужбовці Збройних Сил України та інших військових формувань створених відповідно до чинного законодавства, на перших етапах протистояння змушені були частково дбати про своє екіпірування. Рушійною силою у протистоянні агресору було створення військових підрозділів за територіальним принципом, які забезпечували переважно територіальні громади і населення.

3 огляду на це вище керівництво держави почало ухвалювати дієві політичні рішення не лише щодо реформування системи ресурсного забезпечення, а й зміни у підходах до функціонування сектору безпеки та оборони України. Це було передумовою розроблення нових концептуальних документів 3 оборонного планування в умовах агресії Російської Федерації проти України.

Актуальність теми підтверджено цілями, визначеними у Стратегії національної безпеки України та Стратегії воєнної безпеки України.

Стратегією національної безпеки України [1] передбачено, що Україна зміцнюватиме бойовий потенціал Збройних Сил України, інших органів сил оборони такими шляхами:

удосконаленням та розвитком на основі сучасних технологій систем управління та логістики;

поліпшенням матеріальних умов служби особового складу;

оснащенням новими, зокрема високотехнологічними, зразками озброєння i військової техніки.

Стратегією воєнної безпеки [2] визначено одне 3 найголовніших завдань - ефективний менеджмент у сфері оборони, що грунтується на інноваційних рішеннях, сучасних бізнеспрактиках, програмно-проєктному управлінні оборонними ресурсами, удосконалених процесах визначення та задоволення потреб оборони України.

Також актуальність теми дослідження підтверджено виданням ряду концептуальних документів, спрямованих на реалізацію заходів із розбудови та реформування сектору безпеки та оборони, визначених за результатами його комплексного огляду, а також започаткуванням проведення реформ за нормами, принципами і стандартами НАТО. Ресурсне забезпечення заходів підвищення обороноздатності України $\epsilon$ критичноважливим для успішності реалізації ухвалених рішень в умовах обмеженого фінансування.

Усе вище викладене потребує науково обґрунтованого перегляду наявних підходів до змісту ресурсів та ресурсного забезпечення сектору безпеки і оборони України, що сприятиме їх удосконаленню з урахуванням історичних підходів до організації ресурсного забезпечення та сучасної наукової думки.

\section{Аналіз останніх досліджень та публікацій}

Аналіз останніх досліджень та публікацій за предметним напрямом у теорії стратегічного управління та економічній теорії показав наявність значного обсягу наукових та аналітичних джерел з порушеного питання.

Фундаментальних наукових здобутків в економічній теорії стосовно дослідження категорії ресурсів та їх ефективного використання, досягли такі науковці: Т. Ман, О.
Г. Мірабо, Ф. Кене, П. П. Мерсьє, А. Р. Ж. Тюрго, А. Сміт, Т. Мальтус, Д. Рікардо, Ж. Б. Сей, Д. Мілль, Д. Мейер, Б. Роуен, П. ДіМаджіо, В. Пауел, М. Портер, А. Маршалл, Д. Б. Кларк, К. Менгер, У. С. Джевонс, Л. Вальрас, Дж. Б. Кларк, І. Фішер, А. Пігу, Е. Тофлер.

Неоціненним $€$ внесок у розвиток ресурсних концепцій: Ф. Абраме, Б. Альстренда, І. Ансоффа, П. Друкера, Дж. Лемпела, Г. 
Мінцберга, М. Портера, К. Прахалада, Г. Саймона, А. Стрикленда, А. Томпсона, Г. Хамела, К. Хофера, Е. Чандлера, Г. Штейнера, К. Ендрюса та інших.

Серед вітчизняних науковців, праці яких було досліджено, виокремимо: В. Д. Базилевича, Ю. В Богоявленську, В. Л. Клюня, І. І. Лукінова, С. В. Мочерного, В.Є. Новицького, В. Я. Месель-Веселяка, А. М. Онищенка, Б. І. Пасхавера, С. В. Тищенка, А. В. Черновалова, Г. О. Швиданенка, В. П. Якобчука та інших.
Однак у переважній більшості праць досліджено специфіку набуття економічної переваги, конкурентної переваги та ефективності у підприємницькій діяльності. Натомість специфічною метою сектору безпеки і оборони $є$ забезпечення національної безпеки та оборони на визначеному рівні, що передбачає досягнення певної результативності у протидії загрозам у сфері забезпечення національної безпеки.

\section{Постановка завдання}

Метою статті $\epsilon$ аналіз економічної теорії і теорії стратегічного управління для з'ясування теоретичних положень щодо трансформації змісту економічної категорії "ресурси" та наявних ресурсних концепцій, розуміння їх наукового змісту та шляхів розвитку, щоб надалі розробити сучасну концепцію ресурсного забезпечення сектору безпеки і оборони України.

Для досягнення мети дослідження було проведено її декомпозицію та частково досліджено економічну теорії і теорію стратегічного управління. У ході дослідження використано такі методи теоретичного дослідження: аналіз, синтез, декомпозицію, історичний метод.

\section{Виклад основного матеріалу}

Фундаментальні наукові положення "ресурсного забезпечення" в економічні теорії. Воєнна наука вивчає закономірності збройної боротьби, але ії дослідження неодмінно пов'язано з іншими науками й аспектами людської діяльності. Безумовно, специфіка збройної боротьби залежить від способів управління, економічних умов, якості та кількості застосованих засобів.

Таким чином, насамперед потрібно розглянути економічну теорію. На думку відомого економіста П. Семюельсона, економічна теорія $\epsilon$ наукою про використання суспільством рідкісних ресурсів для виробництва цінних товарів та їх розподілу серед людей. Станом на цей час, найпоширенішими визначеннями економіки $є$ :

1) дослідження поведінки людей у процесі виробництва, розподілу та споживання матеріальних благ і послуг у світі;

2) дисципліна, що вивчає, яким чином суспільство з обмеженими ресурсами визначає перелік товарів і послуг, які потрібно виробляти, та їх споживачів [3, 4].

3 огляду на викладені визначення економіки ключовими напрямами дослідження економіки як науки $є$ ресурси та матеріальні блага, їх виробництво, споживання та розподіл.

Щоб послідовно дослідити зміст ресурсів та ресурсного забезпечення, з'ясуємо поняття "ресурс" як економічну категорію. Так, в економічному словнику "ресурс" визначено як “фундаментальні поняття економічної теорії, що позначають джерела, засоби забезпечення виробництва" [5]. Ресурси виробництва, на думку П. Нарижного [6], є сукупністю природних, соціальних та духовних сил, які можуть бути використані у процесі створення товарів, послуг та інших цінностей.

Досліджуючи питання енергономіки промислового підприємства, С. Д. Бадмаєва [7, с. 34] вважає, що до виробничих ресурсів належить сукупність лише тих ресурсів, що безпосередньо відповідають напрямам виробництва: енергетичні (енергія), трудові ресурси (жива праця), технічні ресурси (засоби праці), матеріальні ресурси (предмет праці). Особливістю виробничих ресурсів можна вважати наявність у них матеріального змісту, тобто розуміти їх як предмети матеріальної діяльності, що мають речову основу.

Відповідно до поглядів американських 
професорів з економіки К. Р. Макконнелла, С. Л. Брю, Ш. Л. Флінна, ресурсами є всі природні, людські й вироблені людиною засоби застосовані для виробництва товарів і послуг [8].

На думку В. Д. Базилевича ресурси - це “сукупність природних, капітальних і людських сил, які потенційно можуть бути використані у процесі виробництва" [9]. Ресурси є базовою економічною категорією.

Як вважає С. В. Мочерний, ресурси $\epsilon$ “сукупністю речових та особистісних факторів виробництва, які використовують для виробництва товарів і послуг” [10].

Досліджуючи економічні ресурси цивілізаційного розвитку, В. Є. Новицький [11] визначає їх як сукупність факторів, що безпосередньо чи опосередковано беруть участь у процесі виробництва або надання послуг.

Також існує думка, що ресурси $є$ тим, що використовують економічні суб'єкти для досягнення визначених цілей i завдань та задоволення власних потреб та потреб зовнішнього середовища [12], або активом (матеріальним чи нематеріальним), яким володіє організація, контролює його чи маючи доступ на постійній основі [13].

Узагальнюючи загальноприйняті В економічній науці трактування, а також спираючись на визначення, наведене в економічному словнику [14], можемо дійти висновку, що економічні ресурси є усім тим, що необхідно для виробництва економічних благ з метою задоволення потреб. Основними видами ресурсів є: праця, земля капітал, підприємницькі здібності.

Британський учений, економіст В. Петті, який започаткував формування концепції, пізніше названої класичною школою політичної економії, виокремив чотири фактори виробництва: основні (земля, праця) та два інші (кваліфікація робітника та засоби його праці запаси, матеріали, інструменти).

Працю, землю, капітал як фактори виробництва визначив засновник класичного напряму сучасної економічної теорії А. Сміт у праці “Дослідження про природу і причини багатства народів" (1775) [15]. Такої ж думки дотримувалися представник класичної школи політекономії французький економіст Ж. Б. Сей, який сформулював теорію "трьох факторів" (економічних ресурсів) [16], та лідер неокласичного напряму в економічній науці $A$. Маршалл [17], який виокремив ще один економічний ресурс - підприємницькі здібності.

Водночас, на думку американського соціолога і футуролога Е. Тофлера, знання $€$ різновидом економічних ресурсів, що ґрунтується на інноваціях, технологічних розробках, науково-технічному прогресі, науці та інформації [18].

Загалом ресурси у широкому розумінні можна класифікувати так:

1) матеріальні - земля, природні (даровані) блага та капітал (економічні блага). Земля $€$ поняттям, що включає безпосередньо землю, надра, водні, лісові та інші ресурси. Капітал $\epsilon$ економічним ресурсом, який може бути виражений у грошовій формі або засобах виробництва (грошовий, або реальний капітал).

2) людські - праця, досвід, знання людей, підприємницька здатність.

У господарській діяльності використовують сукупність ресурсів, що поєднує природні, трудові і капітальні ресурси (капітал). А як економічні ресурси розглядають фінансові ресурси та грошовий капітал.

Узагальнено основні етапи формулювання наукових поглядів на ресурси в економічній та інших теоріях в історичному контексті наведено у таблиці 1.

В Енциклопедії сучасної України [23] як економічні ресурси визначено сукупність матеріальних і нематеріальних факторів та засобів, що забезпечують функціонування та безперебійний процес суспільного виробництва і відтворення. Економічні ресурси прийнято класифікувати на природні (сировина, геофізичні ресурси тощо), трудові (людський капітал), капітальні (фізичний капітал), інформаційні (документи та інше), фінансові (капітал у грошовій формі), обігові кошти, підприємницькі здібності. 
Таблиця 1. - Тенденції ідентифікації ключових ресурсів

\begin{tabular}{|c|c|c|c|}
\hline Школа/напрям & Період & $\begin{array}{l}\text { Ключовий тип } \\
\text { ресурсів }\end{array}$ & Представники школи/напряму \\
\hline $\begin{array}{l}\text { Давньогрецькій } \\
\text { науковці }\end{array}$ & IV ст. до н.е. & Праця & Арістотель \\
\hline Школа меркантилізму & XVI-XVII ст. & Праця & Т. Ман, О. Г. Мірабо \\
\hline $\begin{array}{l}\text { Французька школа } \\
\text { фізіократів }\end{array}$ & XVII-XIX ст. & Земля & Ф. Кене, П. Мерсьє, А. Р. Ж. Тюрго \\
\hline $\begin{array}{l}\text { Класична школа } \\
\text { економічної теорії }\end{array}$ & XVIII-XIX cт. & $\begin{array}{l}\text { Праця, земля, } \\
\text { капітал }\end{array}$ & $\begin{array}{l}\text { А. Сміт, Т. Мальтус, Д. Рікардо, Ж. Б. } \\
\text { Сей, } \\
\text { Д. Мілль }\end{array}$ \\
\hline $\begin{array}{l}\text { Інституційна } \\
\text { організацій }\end{array}$ & $\mathrm{XX} \mathrm{cт.}$ & $\begin{array}{l}\text { Організаційний } \\
\text { процес }\end{array}$ & $\begin{array}{l}\text { Д. Мейер, Б. Роуен, П. ДіМаджіо, В. } \\
\text { Пауел }\end{array}$ \\
\hline $\begin{array}{l}\text { Теорія конкурентних } \\
\text { переваг }\end{array}$ & $\mathrm{XX} \mathrm{cт.}$ & Інформація & М. Портер \\
\hline $\begin{array}{l}\text { Неокласична школа } \\
\text { економічної теорії }\end{array}$ & $\mathrm{XIX}-\mathrm{XX}$ ст. & $\begin{array}{l}\text { Підприємницькі } \\
\text { здібності }\end{array}$ & $\begin{array}{l}\text { Д. Б. Кларк, К. Менгер, } \\
\text { У. С. Джевонс, Л. Вальрас, Дж. Б. } \\
\text { Кларк, І. Фішер, А. Маршалл, А. Пігу }\end{array}$ \\
\hline $\begin{array}{l}\text { Хвильова концепція } \\
\text { розвитку суспільства }\end{array}$ & $\mathrm{XX}-\mathrm{XXI}$ ст. & Знання & Е.Тофлер \\
\hline
\end{tabular}

Примітка: Узагальнено автором на основі джерел [19-22] та джерел, використаних у дослідженні.

Однак в економічній теорії існують й інші варіанти класифікацій економічних ресурсів, що базуються, як правило, на чотирьох складових: земля, праця, капітал і підприємницькі здібності.

Отже, в економічній теорії ресурси також слід розуміти як фактори виробництва. Ресурси мають спільну особливість - потребу у них для створення продуктів, товарів та послуг. Ресурси як правило є рідкісними або обмеженими, тому головна мета економічної науки полягає в такому їх розподілі, що дасть змогу досягти найбільшої переваги (ефективності) у досягненні мети задоволенні потреб. Зміст цієї концепції перегукується з принципом оптимального розподілу ресурсів (факторів).

Питання оптимального розподілу ресурсів відображено у принципі, сформульованому італійським економістом В. Паретто оптимумі Паретто [24]. Одне з його положень полягає в тому, що розподіл ресурсів у суспільстві $\epsilon$ оптимальним, якщо будь-яка зміна такого варіанта розподілу погіршує положення хоча 6 одного 3 учасників економічної системи.

Обмеженість ресурсів в економічній теорії відображено в теорії альтернативних витрат, запропонованій представником австрійської школи політичної економії Ф. Візером [25]. Теорія містить два основних положення: ресурси, призначені для виробництва, завжди обмежені і використання ресурсів для виробництва одних благ виключає використання їх для виробництва інших.

У контексті обмеженості ресурсів розглянемо концепцію нульового зростання розроблену у 70-х роках XX ст. економістами під керівництвом американського ученого Д. Медоуза, одним з ключових положень якої визначено можливість реального економічного зростання лише в разі заощадження природних ресурсів. Концепція нульового зростання пов'язана із концепцією сталого розвитку, в основу якої покладено можливість задоволення потреб суспільства без ризику позбавити майбутні покоління можливості задовольнити свої потреби.

Також прийняття оптимальних рішень в умовах обмежених виробничих ресурсів досліджували представники неокласичної економічної теорії (70-ті роки XIX ст.): У. С. Джевонс, Л. Вальрас, Дж. Б. Кларк, І. Фішер, А. Маршалл та А. Пігу. 
Зазначимо, що фізичні, духовні, соціальні потреби людства $\epsilon$ безмежними, водночас праця, земля та капітал - обмеженими. Виникає очевидна суперечність в необхідності оптимального вибору, визначені альтернатив вибору, обґрунтуванні його критеріїв та ціни (альтернативної вартості).

Аналізуючи економічну теорію, зазначимо, що класична економічна школа виокремлює три фактори виробництва: працю, землю, капітал. У марксистській теорії фактори виробництва поділено на речові (засоби виробництва) та особистісні (робоча сила). Маржиналістська теорія визначає додатковий фактор - підприємницьку здатність [26], так званий підприємницький талан. Крім того, І. Нонака, Х. Такеучі, Р. Вільямс, В. Л. Іноземцев, В. В. Глухов, С. Б. Коробко, Т. В. Мариніна, С. М. Климов, О. Н. Шуть, У. Букович, А. В. Вебер, А. Д. Данілов, С. Й. Шифрін, М. К. Румізен вважають інформацію п'ятим фактором виробництва [27].

У теорії конкурентних переваг значну роль відіграє "положення про національний ромб", розроблене професором Гарвардської школи бізнесу, американським економістом М. Портером. Одним із чотирьох елементів національного ромба визначено необхідність постійної імплементації інновацій, новітніх технологій з опертям на ресурс знань та високий рівень розвитку інфраструктури (інформації, зв'язку, транспортної системи) [28].

3 огляду на значущість ресурсу “знання" та високий рівень розвитку інфраструктури зупинимося на теорії лінійного програмування, розробленій Л. В. Канторовичем [29]. Учений запропонував математичний метод пошуку оптимального варіанта розподілу ресурсів, що підштовхнуло до використання електроннообчислювальної техніки у вирішенні економічних завдань і можливість створювання моделей ефективного розподілу та оцінювання ресурсів.

В ході аналізу економічної науки виявлено тенденцію до виокремлення екологічного фактора та фактор часу.
Таким чином, розглядаючи фактори виробництва, наголосимо, що ресурси одночасно мають дві ключові характеристики: з одного боку, це джерела та інструменти, за допомогою яких досягають задоволення потреб, а з іншого - сукупність факторів, що безпосередньо впливають на виробництво та перебіг процесів для задоволення потреб.

Кожен із розглянутих факторів виробництва (праця, капітал, земля, підприємницька здібність) $€$ джерелом формування відповідних типів доходу заробітної плати, проценту, ренти, прибутку.

Відповідно до сучасної ресурсної концепція факторами виробництва вважають технічні ресурси (оборотні та необоротні активи), технології, просторові ресурси (будівлі, землю), інформаційні, людські, фінансові ресурси, управління та підприємницькі здібності.

В сучасних умовах функціонування успішна конкурентоспроможність насамперед залежить від технологічних та інформаційних ресурсів і підприємницьких здібностей суб'єктів управління діяльністю.

Станом на цей час, класичний підхід до розподілу ресурсів (земля, праця, капітал) трансформувався у широкий спектр матеріальних та нематеріальних ресурсів підприємства.

Загалом, економічна теорія стала вихідною точкою у формуванні нової науки стратегічного управління, у межах якої, під впливом економічної та інших наук розвинулися дослідження змісту та значущості ресурсів у процесі функціонування підприємства, а також визначення його конкурентних переваг. Отже, основними концепціями ресурсного підходу можна вважати: класичну ресурсну концепцію, концепцію динамічних здатностей, концепцію ресурсних асиметрій. Проаналізуємо їх у межах теорії стратегічного управління.

Наукові положення "ресурсного забезпечення" в теорії стратегічного управління. 3 60-х років XX ст. для розмежування підходів до управління 
організацією на найнижчому рівні і на рівні вищого керівництва було введено термін “стратегічне управління" [30]. Як стратегічне управління розуміли необхідність зосередження уваги вищого керівництва на зовнішньому середовищі функціонування організації для своєчасного реагування на зміни у ньому. Першими стратегічне управління розглядали: Ф. Абраме, Б. Альстренд, І. Ансофф, П. Друкер, Дж. Лемпел, Г. Мінцберг, Т. Питере, М. Портер, К. Прахалад, Г. Саймон, А. Стрикленд, А. Томпсон, Г. Хамел, К. Хофер, Е. Чандлер, Г. Штейнер, К. Ендрюс та інші.

Станом на цей час, поштовхом для розвитку сучасних ресурсних концепцій у теорії стратегічного управління стали фундаментальні праці Дж. Барна, Б. Вернерфельта, К. Коннера, Е. Пренроуза, К. Прахалада, Р. Рамелта, Д. Тиса та інших. Їх наукові праці не лише стали надбанням економічної теорії, а й вплинули на формування теорії стратегічного управління.

у монографії колективу науковців за редакцією Г. О. Швиданенко про дослідження управління ресурсами підприємства [31] на підставі аналізу наявних ресурсних підходів (концепцій) сформульовано основні напрями ресурсної теорії:

1) класична ресурсна концепція Вернерфельт, Е. Пенроуз);

2) концепція ключових компетенцій (Г. Хамел, К. Прахалад);

3) концепція динамічних здатностей (Г. Пізано, Р. Грант, Д. Колліз, С. Ментгомері, Д. Тіс та ін.);

4) комбінаційні концепції ресурсної теорії (теорія ресурсних переваг) (Х. Шелбі, Р. Морган) [32].

У класичній ресурсній концепції спочатку виокремлювали дві складових ресурсів (фактори виробництва й активи), які у процесі і розвитку ресурсної концепції трансформувалися у чотири взаємопов'язані категорії: ресурси, компетентності, здібності, організаційну рутину.

У теорії стратегічного управління і у теоріях, використаних під час їі формування, як категорію ресурсів розуміють усе, що дає змогу комерційному підприємству формувати та реалізовувати власні стратегії, спрямовані на підвищення його економічної та управлінської ефективності [33-36].

Досліджуючи ресурсну концепцію в теорії стратегічного управління, Н. В. Єгорова і Т. Ю. Каламбет роблять висновок про розбіжності у науковій думці між необхідністю включення здібностей до складу ресурсів підприємства та визначеною їх важливістю у підвищенні продуктивності наявних ресурсів для перетворення факторів виробництва у результати.

Представники неокласичної школи економічної теорії (XIX-XX ст.) Д. Б. Кларк, К. Менгер, У. С. Джевонс, Л. Вальрас, Дж. Б. Кларк, І. Фішер, А. Маршалл, А. Пігу розглядали підприємницькі здібності як фактор виробництва, тотожний ресурсам, наявним у відповідному володінні.

Як організаційну рутину можна розуміти процеси, які виконує на підприємстві попередньо навчений персонал відповідної кваліфікації, акумулюючи певні знання, що надалі стають основою для формування унікальності підприємства в контексті використання наявних ресурсів. Знання та досвід персонал може набути, але в жодному разі не скопіювати у конкурентів [37]. Компетенції персоналу доцільно розглядати насамперед як результат синтезу ресурсів і здатностей та їх сукупного впливу на ефективність відповідної діяльності [43].

Один із головних принципів класичної ресурсної концепції полягає у здатності підприємства сформулювати відповідну стратегію розвитку, що передбачає розвиток здібностей, які формують необхідні компетенції для отримання перспективних конкурентних переваг.

У класичній ресурсній концепції слід звернути увагу на наявність вимог, які висувають до ресурсів підприємства. Їх сформулював Дж. Барні і позначив абревіатурою VRIO, де, V - Valuable (цінність), R - Rare (рідкісність), I - Imperfectly imitable (ідеальна відтворюваність), O - Organizational capabilities (організаційні здатності) [38]. 
Отже, для реалізації підходів на яких грунтується ресурсна концепція, необхідно ідентифікувати унікальні ресурси підприємства, що можуть бути використані як джерело конкурентних переваг.

Також, звернемо увагу на концепцію ключових компетенцій (Г. Хамел, К. Прахалад), яка базується унікальності ключової компетенції підприємства, сформованої завдяки синтезу знань, досвіду, вмінь та навичок, що дає змогу бути лідером у певному сегменті ринку [39].

У концепції динамічних здатностей (Г. Пізано, Р. Грант, Д. Колліз, С. Ментгомері, Д. Тіс та інші) наголошено на необхідності випереджувальних дій підприємства, спрямованих на відповідність майбутньому середовищу функціонування. Так, на думку В. С. Катькало [40], стратегії, які передували ресурсному підходу, вважали реактивними через намагання компаній відповідати умовам зовнішнього середовища, але ресурсний підхід, що базується на динамічних здатностях, зумовив пошук випереджувального створення унікальних ресурсів та здібностей і започаткував проактивній погляд на формування відповідних стратегій.

У концепції ресурсних асиметрій ключовим моментом в отриманні конкурентних переваг $\epsilon$ ідентифікація ресурсів, аналогів яких не мають конкуренти [41].

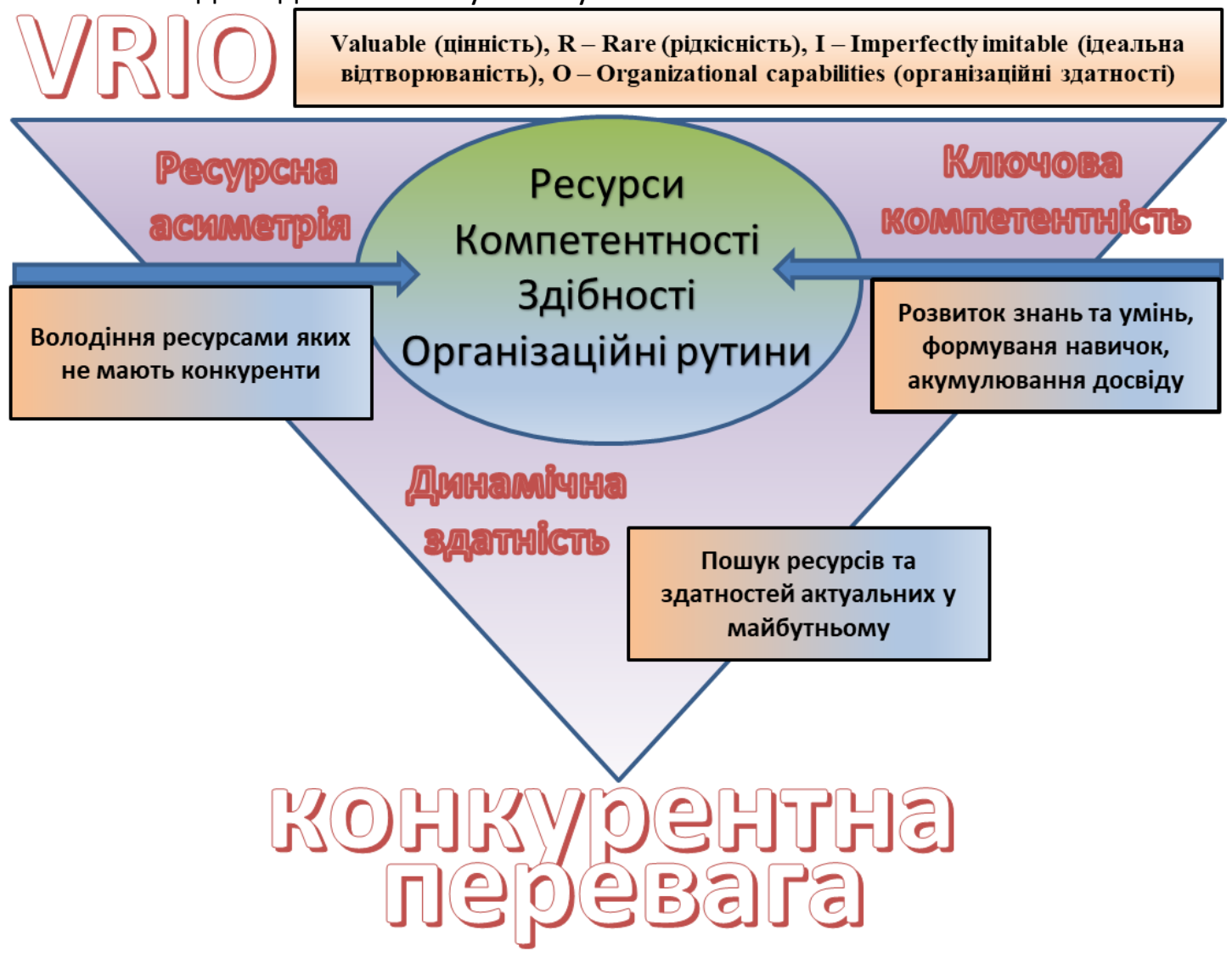

Мал. 1. - Досягнення конкурентної переваги відповідно до положень ресурсних концепцій (розроблено автором)

Розглянуті ресурсні концепції спрямовані передусім направлені на пошук комерційним підприємством шляхів підвищення своєї ефективності та набуття конкурентних переваг через наявність унікальних матеріальних та нематеріальних ресурсів. Це зумовлено цілями, які ставить собі комерційне підприємство: максимальної виробничої ефективності та високого рівня конкурентоспроможності, що полягає у набутті конкурентних переваг.

Ресурсний підхід в управлінні 
підприємством ґрунтується на унікальності кожного суб'єкта господарювання, де ключовими моментами досягнення високої прибутковості є використання та експлуатація саме відмінностей підприємств, а не копіювання їх поведінки та підходів до організації управління і функціонування.

Загалом можна виокремити дві важливі відмінності стратегічного мислення, що ґрунтується на ресурсному підході:

1) пріоритетність створення цінності на противагу мінімізації витрат;

\section{Висновки}

Станом на цей час класичний підхід до розподілу ресурсів (земля, праця, капітал) трансформувався у підхід, що ґрунтується на застосуванні широкого спектру матеріальних та нематеріальних ресурсів підприємства.

Головною метою функціонування системи сектору безпеки та оборони $\epsilon$ захист національних інтересів України від загроз та забезпечення національної безпеки України на відміну від комерційного підприємства, де головними цілями $є$ максимальна ефективність комерційної діяльності та висока конкурентоспроможність, якої досягають через набуття конкурентних переваг.

Розглянуті ресурсні концепції у теорії стратегічного управління, як правило, спрямовані на отримання підприємством конкурентної переваги завдяки володінню певними ресурсами: компетентністю, здатністю, організаційною рутиною.

Однак, безпосередньо наукового підходу до функціонування саме системи ресурсного забезпечення зазначені підходи не визначають.

Водночас, виявлені особливості розглянутих підходів, зміст ключових категорій та пріоритетність у набутті конкурентних переваг учасниками економічних відносин можуть бути
2) зосередження головних зусиль не на перемозі над конкурентами будь-якою ціною, а на створенні власних, складних для копіювання іншими компаніями компетенцій як передумов лідерства у бізнесі [42].

На підставі аналізу ресурсного підходу у стратегічному управлінні можна фрагментарно зобразити площину визначених категорій для формулювання часткових вимог до ресурсів перспективної концепції (мал. 1).

використані під час розроблення концепції ресурсного забезпечення сектору безпеки та оборони.

На нашу думку, перспективна ресурсна концепція сектору безпеки та оборони України має бути орієнтована на підхід, застосований у теорії стратегічного управління, але 3 відповідною градацією типів ресурсів, урахуванням поглядів сучасної економічної теорії i сучасного менеджменту та “філософської трійки” - місії, бачення, цінностей. У ході розроблення сучасної концепції ресурсного забезпечення сектору безпеки та оборони необхідно обов'язково враховувати головні категорії ресурсної концепції: ресурси, здібності, компетентності, організаційну рутину.

Перспективу подальших досліджень вбачаємо в аналізі сучасних наукових положень у сфері ресурсного забезпечення в теорії воєнної науки і теорії державного управління. Зазначене зумовлено тим, що головною метою функціонування системи сектору безпеки та оборони, на відміну від комерційного підприємства, $€$ захист національних інтересів України від загроз та забезпечення національної безпеки України.

2. Про Стратегію воєнної безпеки України: Про рішення Ради національної безпеки i оборони України від 25 березня 2021 року Указ Президента України №121/2021. 
3. Історія економічних вчень : курс лекцій / В.Л. Клюня, А. В. Черновалов, Ж. В. Черновалова. Мінськ : БГУ, 2016.

4. Samuelson, P. Economics (13th Ed.). 1989. McGraw Hill. p. 837

5. Райзберг Б. А., Лозовський Л. Ш., Стародубцева Е. Б. Сучасний Економічний словник [Текст] / Б. А. Райзберг, Л. Ш. Лозовський, Є. Б. Стародубцева. 5-е вид., Перероб. і доп. - М.: ІНФРА-му, 2007.

6. Нарижний П. І. Виробничі ресурси як економічна категорія. URL: https://cutt.ly/Xb0Gk1R (дата звернення 19.05.2021).

7. Бадмаєва, С. Д. Енергономіка промислового підприємства [Текст]: монографія / С.Д. Бадмаєва. - СПб.: СПбЛТА, 2000.

8. McConnell, Campbell. Economics: Principles, Problems, \& Policies: [англ.] / Campbell McConnell, Stanley Brue, Sean Flynn. - 22st Ed. - McGraw-Hill, 2021. - ISBN 9781260226775.

9. Економічна теорія : Політекономія : підручник / за ред. В. Д. Базилевича. - 6-те вид., переробл. і допов. - К. : Знання-Прес, 2007. - С. 120.

10. Мочерний С. В. Політекономія : підручник / С. В. Мочерний. - К. : Вікар, 2003. - С. 40.

11. Новицький В.Є. Економічні ресурси цивілізаційного розвитку: навч. посібник / В.Є. Новицький - К.: НАУ, 2004. - 268 с.

12. Французова М. А. Сутність ресурсного забезпечення діяльності організації. Транспортне справа. 2008. № 3. С. 12.

13. Helfat C., Peteraf M. The dynamic resourcebased view: capability life cycles. Strategic Management Journal. 2003. № 24. P. 997.

14. Економічний словник: Довідкове видання/ В. І. Нечаєв, П. В. Михайлушкін. - Краснодар. /Краснодар, “Атри”, 2011. - 464 с.

15. Сміт А. Багатство народів. Дослідження про природу та причини добробуту націй / пер. Олександра Васильєва. - К.: Наш Формат, 2018. - 722 c. — ISBN 978-617-7552-14-6.

16. Лукінов І. І., Месель-Веселяк В. Я., Онищенко А. М., Пасхавер Б. І. Організаційні фактори в системі формування і використання ресурсного потенціалу підприємств. Формування системи і механізмів обліково-аудиторського та аналітичного забезпечення конкурентоспроможного розвитку підприємств реального сектору економіки України: матеріали міжнар. конф., 2012. С.69.

17. Dimand, Robert W. "Keynes, IS-LM, and the Marshallian Tradition". History of Political Economy. Duke University Press. 2007. № 39(1): 81-95. DOI: 10.1215/00182702-2006024

18. Кошелєв А. М. Національна економіка: конспект лекцій. URL: https://econ.wikireading.ru/30085 (дата звернення 26.05.2021).

19. Проскурін П. В. Історія економіки та економічних учень. Нариси економічної історії індустріальної цивілізації: Навч. пос. (укр.). Київ: КНЕУ. 2005.

20. Блауг М. Ман, Томас // 100 великих економістів до Кейнса = Great Economists before Keynes: An introduction to the lives \& works of one hundred great economists of the past. - СПб .: Економікус, 2008. - 352 c.

21. Jonathan Barnes. Aristotle: a very short introduction. - Oxford: Oxford University Press, 2000. - 160 c. - ISBN 0192854089.

22. Якобчук В. П., Богоявленська Ю. В., Тищенко С. В. Історія економіки та економічної думки: навч. посіб. / В. П. Якобчук, Ю. В. Богоявленська, С. В. Тищенко. Київ: Центр учбової літератури, 2015.

23. Кіреєв С. І. Економічні ресурси // Енциклопедія Сучасної України: електронна версія [веб-сайт] / гол. редкол.: І.М. Дзюба, А.І. Жуковський, М.Г. Железняк та ін.; НАН України, НТШ. Київ: Інститут енциклопедичних досліджень НАН України, 2006. URL: https://cutt.ly/GbOHvOQ (дата звернення 19.05.2021).

24. Подиновский В. В., Ногин В. Д. Паретооптимальные решения многокритериальных задач. Физматлит, 2007. URL: https://cutt.ly/ubOHUWD (дата звернення 19.05.2021).

25. Скрипник M. I. Сутність витрат як економічної категорії. Вісник Житомирського державного 
технологічного університету. Серія:

Економічні науки. 2009. URL: https://cutt.ly/JbOHKzy (дата звернення 19.05.2021).

26. Історія економічних вчень : курс лекцій / В. Л. Клюня, А. В. Черновалов, Ж. В. Черновалова. - Мінськ : БГУ, 2016.

27. Управління ресурсами підприємства [Електронний ресурс] : монографія / за заг. ред. к.е.н., проф. Г. О. Швиданенко. Київ : KHEУ, 2014. 418 c.

28. Бартенєв С. А. Історія економічних вчень у питаннях та відповідях. Москва : Юрист, 1998, 186 c.

29. Канторович Л. В. Економічний розрахунок найкращого використання ресурсів. Москва : Вид. АН СРСР, 1959.

30. Філімонов Д. А. Тенденції розвитку стратегічного управління як науки. Економічні науки. 59(1). 2017. URL: https://novainfo.ru/article/11115 (дата звернення 19.05.2021).

31.Управління ресурсами підприємства [Електронний ресурс] : монографія / за заг. ред. к.е.н., проф. Г. О. Швиданенко. Київ : KHEY, 2014. 418 c.

32. Hunt, Shelby D., Robert H. Morgan. The comparative advantage theory of competition. Journal of Marketing. 1995. № 59. P. 1-15. URL:

https://www.jstor.org/stable/1252069?seq=1 (дата звернення 26.05.2021).

33. Єгорова Н. В., Каламбет Т. Ю. Ресурсна концепція в теорії стратегічного управління. Ефективна економіка. 2013. № 7. URL: http://www.economy.nayka.com.ua/?op=1\&z $=2204$ (дата звернення 19.05.2021).

34. Катькало В. С. Ресурсна концепція стратегічного управління: генезис основних ідей і понять. Вісник Санкт-Петербурзького університету. Менеджент. 2002. №4. C. 20-42.

35. Ягафарова Е. Ф. Стійкість конкурентного перевага з точки зору ресурсної концепції. Bicmi Пензенського державного педагогічного університету ім. В. Г. Бєлінського. 2008. № 10. С. 30-35.

36. Рікардо Д. Передумови політичної економії та оподаткування / Давид Рікардо. - 1817. С. 32-44.

37. Нельсон Р., Уінтер С. Еволюційна теорія економічних змін. Москва: Справа, 2002. $61 \mathrm{c}$.

38. Knott P. J. Does VRIO help managers evaluate a firm's resources? Management Decision. 2015. URL: https://cutt.ly/zb0J4Tx (дата звернення 19.05.2021).

39. Prahalad C. K. The core competence of the corporation. Harvard business review. 1990. № 68. P. 79-91.

40. Катькало В. С. Теорія стратегічного управління: етапи розвитку та основні парадигми. Вісник Санкт-Петербурзького університету. Менеджмент. 2002. 3(24). С. 3-23.

41. Управління ресурсами підприємства [Електронний ресурс] : монографія / за заг. ред. к.е.н., проф. Г. О. Швиданенко. Київ : KHEY, 2014. 418 c.

42. Катькало В. С. Місце і роль ресурсної концепції в розвитку теорії стратегічного управління (передмова до розділу). Вісник Санкт-Петербурзького університету. Менеджмент. 2003. № 3. С. 3-14.

43. Єгорова, Н. В., Каламбет, Т. Ю. Ресурсна концепція в теорії стратегічного управління. Ефективна економіка. 2013. № 7. URL: http://www.economy.nayka.com.ua/?op $=1 \& z$ $=2204$ (дата звернення 19.05.2021).

\section{Анализ научных положений ресурсных концепций в экономической теории и теории стратегического управления}

\footnotetext{
Анатолий Лойшин ${ }^{1}$ А

Corresponding author: доктор философии, старший преподаватель, e-mail: aloishyn@gmail.com, ORCID: 0000-0003-2769-9336

${ }^{\text {А } Н а ц и о н а л ь н ы и ̆ ~ у н и в е р с и т е т ~ о б о р о н ы ~ У к р а и н ы ~ и м е н и ~ И в а н а ~ Ч е р н я х о в с к о г о, ~ п р-к т ~ В о з д у х о ф л о т с к и и ̆, ~ 28, ~ г . ~ К и е в, ~ 03049, ~ У к р а и н а ~}$
} 


\begin{abstract}
Аннотация
В статье обобщены аргументы и контраргументы в научной дискуссии по вопросу разработки современной концепции ресурсного обеспечения сектора безопасности и обороны Украины. Целью исследования является анализ экономической теории и теории стратегического управления о наличии теоретических положений о трансформации содержания экономической категории "ресурсы" и ресурсных концепций для понимания их научного содержания, и предпосылок развития для разработки современной концепции ресурсного обеспечения сектора безопасности и обороны Украины. На основании систематизации литературных источников и подходов к решению проблемы ресурсного обеспечения сектора безопасности и обороны Украины определено, что в экономической теории и теории стратегического управления имеющиеся подходы, которые могут быть использованы в дальнейших исследованиях предметной области. Актуальность решения этой научной проблемы подтверждают меры, инициированные руководством государства в соответствии с концептуальными документами государственного управления и оборонного планирования. Предметную плоскость в статье исследовано в такой логической последовательности: проанализированы экономическую теорию, затем - теорию стратегического управления, сформулированы выводы. Методическим инструментарием проведенного исследования стали анализ, синтез, декомпозиция, исторический метод. В исследовании приведены результаты эмпирического анализа экономической теории и теории стратегического управления, а именно отмечено, что в ходе разработки современной концепции ресурсного обеспечения сектора безопасности и обороны необходимо учитывать основные категории ресурсной концепции: ресурсы, способности, компетентности, организационную рутину. В исследовании эмпирически подтверждено и теоретически доказано, что вопросы научного исследования ресурсов как экономической категории и операций с ними является актуальным со времен Аристотеля, что подтверждается постоянным поиском механизмов оптимального их использования с учетом фактора ограниченности. Результаты проведенного исследования могут быть полезными для ученых и управленцев, изучающих проблематикой всестороннего обеспечения в сфере сектора безопасности и обороны Украины.
\end{abstract}

Ключевые слова: ресурсы, ресурсная концепция, экономическая теория, стратегическое управление.

\title{
Analysis of scientific provisions of resource concepts in economic theory and theory of strategic management
}

\author{
Anatolii Loishyn ${ }^{1 \mathrm{~A}}$ \\ Corresponding author: ${ }^{1}$ Ph. D., Senior lector of Department of financial support, e-mail: aloishyn@gmail.com, ORCID: 0000-0003-2769-9336 \\ A National Defence University of Ukraine named after Ivan Cherniachovskyi, 28, Povitroflotsky, ave, Kyiv, 03049, Ukraine
}

\begin{abstract}
The article summarizes the arguments and counterarguments in a scientific discussion on the development of a modern concept of resource support for the security and defence sector of Ukraine. The aim of the study is to analyze the economic theory and the theory of strategic management on the presence of theoretical provisions on the transformation of the content of the economic category "resources" and resource concepts for understanding their scientific content, and development prerequisites for the development of a modern concept of resource provision for the security and defence sector of Ukraine. Based on the systematization of literary sources and approaches to solving the problem of resource support for the security and defence sector of Ukraine, it is determined that there are approaches in economic theory and the theory of strategic management that can be used in further studies of the subject area. The urgency of solving this scientific problem is confirmed by the measures initiated by the state leadership in accordance with the conceptual documents of state administration and defence planning. The subject plane in the article is investigated in the following logical sequence: economic theory is analyzed, then - the
\end{abstract}


theory of strategic management, conclusions are formulated. Analysis, synthesis, decomposition, and the historical method became the methodological tools of the study. The study presents the results of an empirical analysis of economic theory and the theory of strategic management, namely, it is noted that in the course of developing a modern concept of resource support for the security and defence sector, it is necessary to take into account the main categories of the resource concept: resources, abilities, competencies, organizational routine. The study empirically confirmed and theoretically proved that the issues of scientific research of resources as an economic category and operations with them have been relevant since the time of Aristotle, which is confirmed by the constant search for mechanisms for their optimal use, taking into account the limiting factor. The results of the study can be useful for scientists and managers studying the issues of comprehensive support in the field of the security and defence sector of Ukraine.

Keywords: resources, resource concept, economic theory, strategic management.

\section{References}

1. Pro rishennya Rady natsional'noyi bezpeky i oborony Ukrayiny vid 14 veresnya 2020 roku "Pro Stratehiyu natsional'noyi bezpeky Ukrayiny" [On the decision of the National Security and Defense Council of Ukraine of September 14, 2020 "On the National Security Strategy of Ukraine"]: Ukaz Prezydenta Ukrayiny №392/2020.

2. Pro rishennya Rady natsional'noyi bezpeky i oborony Ukrayiny vid 25 bereznya 2021 roku "Pro Stratehiyu voyennoyi bezpeky Ukrayiny» [On the decision of the National Security and Defense Council of Ukraine of March 25, 2021 "On the Strategy of Military Security of Ukraine"]: Ukaz Prezydenta Ukrayiny №121/2021.

3. History of economic doctrines: a course of lectures [History of economic doctrines: a course of lectures] / V. L. Klyunya, A. V. Chernovalov, Zh. V. Chernovalova. Minsk: BSU, 2016.4. P. Samuelson. Economics (13th Ed.). 1989. McGraw Hill. p. 837

5. Rayzberh B. A., Lozovs'kyy L. SH., Starodubtseva E. B. Suchasnyy Ekonomichnyy slovnyk [Modern Economic Dictionary] [Tekst] / B. A. Rayzberh, L. SH. Lozovs'kyy, YE. B. Starodubtseva. 5-e vyd., Pererob. i dop. Moscow: INFRA-mu, 2007.

6. Naryzhnyy P. I. Vyrobnychi resursy yak ekonomichna katehoriya [Production resources as an economic category]. Available from: https://cutt.ly/Xb0Gk1R (data zvernennya 19.05.2021).

7. Badmayeva, S.D. Enerhonomika promyslovoho pidpryyemstva [Energonomics of industrial enterprise] [Tekst]: monohrafiya / S.D. Badmayeva. SPb.: SPbLTA, 2000.

8. McConnell, Campbell. Economics: Principles, Problems, \& Policies: [англ.] / Campbell McConnell, Stanley Brue, Sean Flynn. - 22st Ed. - McGraw-Hill, 2021. - ISBN 9781260226775.

9. Ekonomichna teoriya : Politekonomiya : pidruchnyk [Economic theory: Political economy: a textbook] / za red. V. D. Bazylevycha. - 6-te vyd., pererobl. i dopov. K. : Znannya-Pres, 2007. - S. 120.

10. Mochernyy S. V. Politekonomiya : pidruchnyk [Political economy: textbook] / S. V. Mochernyy. Kyiv : Vikar, 2003. S. 40.

11. Novyts'kyy V.YE. Ekonomichni resursy tsyvilizatsiynoho rozvytku: navch. Posibnyk [Economic resources of civilization development: textbook. Manual] / V.YE. Novyts'kyy. Kyiv: NAU, 2004. 268 s.

12. Frantsuzova M. A. Sutnist' resursnoho zabezpechennya diyal'nosti orhanizatsiyi [he essence of resource provision of the organization]. Transportne sprava. 2008. № 3. S. 12.

13. Helfat C. \& Peteraf M. The dynamic resourcebased view: capability life cycles. Strategic Management Journal. 2003. № 24. P. 997.

14. Ekonomichnyy slovnyk: Dovidkove vydannya [Economic dictionary: Reference edition] / V. I. Nechayev, P. V. Mykhaylushkin. - Krasnodar. / Krasnodar, "Atry", 2011. - $464 \mathrm{~s}$.

15. Smit A. Bahat.stvo narodiv. Doslidzhennya pro pryrodu ta prychyny dobrobutu natsiy [Wealth of nations. Research on the nature and causes 
of the well-being of nations] / per. Oleksandra Vasyl'yeva. Kyiv: Nash Format, 2018. 722 s. ISBN 978-617-7552-14-6.

16. Lukinov I. I., Mesel'-Veselyak V. YA., Onyshchenko A. M., Paskhaver B. I. Orhanizatsiyni faktory $v$ systemi formuvannya i vykorystannya resursnoho potentsialu pidpryyemstv. Formuvannya systemy i mekhanizmiv oblikovo-audytors'koho ta analitychnoho zabezpechennya konkurentospromozhnoho rozvytku pidpryyemstv real'noho sektoru ekonomiky Ukrayiny [Organizational factors in the system of formation and use of resource potential of enterprises. Formation of the system and mechanisms of accounting and auditing and analytical support of competitive development of enterprises of the real sector of the economy of Ukraine]: materialy mizhnar. konf., 2012. S.69.

17. Dimand, Robert W. "Keynes, IS-LM, and the Marshallian Tradition". History of Political Economy. Duke University Press. 2007. № 39(1): 81-95. DOI: 10.1215/001827022006-024

18. Koshelyev A. M. Natsional'na ekonomika: konspekt lektsiy [National economy: lecture notes].

URL: https://econ.wikireading.ru/30085.

19. Proskurin P. V. Istoriya ekonomiky ta ekonomichnykh uchen'. Narysy ekonomichnoyi istoriyi industrial'noyi tsyvilizatsiyi [History of economics and economic doctrines. Essays on the economic history of industrial civilization]: Navch. pos. (ukr.). Kyiv: KNEU. 2005.

20. Blauh M. Man, Tomas // 100 velykykh ekonomistiv do Keynsa $=$ Great Economists before Keynes: An introduction to the lives \& works of one hundred great economists of the past $[100$ great economists before Keynes = Great Economists before Keynes: An introduction to the lives \& works of one hundred great economists of the past]. - SPb.: Ekonomikus, 2008. - $352 \mathrm{~s}$.

21. Jonathan Barnes. Aristotle: a very short introduction. - Oxford: Oxford University Press, 2000. - 160 c. — ISBN 0192854089.
22. Yakobchuk V. P., Bohoyavlens'ka YU. V., Tyshchenko S. V. Istoriya ekonomiky ta ekonomichnoyi dumky [History of economics and economic thought] : navch. posib. / V. P. Yakobchuk, YU. V. Bohoyavlens'ka, S. V. Tyshchenko. Kyiv: Tsentr uchbovoyi literatury, 2015.

23. Kireyev S. I. Ekonomichni resursy // Entsyklopediya Suchasnoyi Ukrayiny: elektronna versiya [Encyclopedia of Modern Ukraine: electronic version] [veb-sayt] / hol. redkol.: I.M. Dzyuba, A.I. Zhukovs'kyy, M.H. Zheleznyak ta in.; NAN Ukrayiny, NTSH. Kyyiv: Instytut entsyklopedychnykh doslidzhen' NAN Ukrayiny, 2006. Available from: https://cutt.ly/GbOHv0Q (data zvernennya 19.05.2021).

24. Podinovskiy V. V., Nogin V. D. Paretooptimal'nyye resheniya mnogokriterial'nykh zadach [Pareto-optimal solutions of multicriteria problems]. Fizmatlit, 2007. Available from: https://cutt.ly/ubOHUWD (data zvernennya 19.05.2021).

25. Skrypnyk M. I. Sutnist' vytrat yak ekonomichnoyi katehoriyi [The essence of costs as an economic category]. Visnyk Zhytomyrs'koho derzhavnoho tekhnolohichnoho universytetu. Seriya: Ekonomichni nauky. 2009. Available from: https://cutt.ly/JbOHKzy (data zvernennya 19.05.2021).

26. Istoriya ekonomichnykh vchen' [History of economic doctrines: a course of lectures] : kurs lektsiy / V. L. Klyunya, A. V. Chernovalov, ZH. V. Chernovalova. Mins'k : BHU, 2016.

27. Upravlinnya resursamy pidpryyemstva [Upravlinnia resursy pidpryiemstva] [Elektronnyy resurs] : monohrafiya / za zah. red. k.e.n., prof. H. O. Shvydanenko. Kyiv : KNEU, 2014. $418 \mathrm{~s}$.

28. Bartenyev S. A. Istoriya ekonomichnykh vchen' u pytannyakh ta vidpovidyakh [History of economic doctrines in questions and answers.]. Moskva : Yuryst, 1998, $186 \mathrm{~s}$.

29. Kantorovych L. V. Ekonomichnyy rozrakhunok naykrashchoho vykorystannya resursiv [Economic calculation of the best use of resources]. Moskva : Vyd. AN SRSR, 1959. 
30. Filimonov D. A. Tendentsiyi rozvytku stratehichnoho upravlinnya yak nauky [Trends in the development of strategic management as a science]. Ekonomichni nauky. 59(1). 2017. Available from: https://novainfo.ru/ article/11115 (data zvernennya 19.05.2021).

31. Upravlinnya resursamy pidpryyemstva [Enterprise resource management] [Elektronnyy resurs] : monohrafiya / za zah. red. k.e.n., prof. H. O. Shvydanenko. Kyiv : KNEU, 2014. $418 \mathrm{~s}$.

32. Hunt, Shelby D., Robert H. Morgan. The comparative advantage theory of competition. Journal of Marketing. 1995. № 59. P. 1-15. Available from: https://www.jstor.org/stable/1252069?seq=1 (data zvernennya 26.05.2021).

33. Yehorova N. V., Kalambet T. YU. Resursna kontseptsiya $v$ teoriyi stratehichnoho upravlinnya [esource concept in the theory of strategic management]. Efektyvna ekonomika. 2013. № 7. Available from: http://www.economy.nayka.com.ua/?op=1\&z =2204 (data zvernennya 19.05.2021).

34. Kat'kalo V. S. Resursna kontseptsiya stratehichnoho upravlinnya [Resource concept of strategic management: genesis of basic ideas and concept]: henezys osnovnykh idey $\mathrm{i}$ ponyat'. Visnyk Sankt-Peterburz'koho universytetu. Menedzhment. 2002. №4. S. 2042.

35. Yahafarova E. F. Stiykist' konkurentnoho perevaha z tochky zoru resursnoyi kontseptsiyi [Sustainability of competitive advantage in terms of resource concept]. Visti Penzens'koho derzhavnoho pedahohichnoho universytetu im. V.H. Byelins'koho. 2008. № 10. S. 30-35.

36. Rikardo D. Peredumovy politychnoyi ekonomiyi ta opodatkuvannya [Prerequisites of political economy and taxation] / Davyd Rikardo. 1817. S. 32-44.

37. Nel'son R., Uinter S. Evolyutsiyna teoriya ekonomichnykh zmin [Evolutionary theory of economic change]. Moskva: Sprava, 2002. $61 \mathrm{~s}$.

38. Knott P. J. Does VRIO help managers evaluate a firm's resources? Management Decision. 2015. Available from: https://cutt.ly/zb0J4Tx (дата звернення 19.05.2021).

39. Prahalad C. K. The core competence of the corporation. Harvard business review. 1990. № 68. P. 79-91.

40. Kat'kalo V. S. Teoriya stratehichnoho upravlinnya: etapy rozvytku ta osnovni paradyhmy [Theory of strategic management: stages of development and basic paradigms]. Visnyk Sankt-Peterburz'koho universytetu. Menedzhment. 2002. 3(24). S. 3-23.

41. Upravlinnya resursamy pidpryyemstva [Upravlinnia resursy pidpryiemstva] [Elektronnyy resurs] : monohrafiya / za zah. red. k.e.n., prof. H. O. Shvydanenko. Kyiv : KNEU, 2014. $418 \mathrm{~s}$.

42. Kat'kalo V. S. Mistse i rol' resursnoyi kontseptsiyi $\vee$ rozvytku teoriyi stratehichnoho upravlinnya [The place and role of the resource concept in the development of the theory of strategic management] (peredmova do rozdilu). Visnyk Sankt-Peterburz'koho universytetu. Menedzhment. 2003. № 3. S. 314.

43. Yehorova, N. V., Kalambet, T. YU. Resursna kontseptsiya $v$ teoriyi stratehichnoho upravlinnya [Resource concept in the theory of strategic management]. Efektyvna ekonomika. 2013. № 7. Available from: http://www.economy.nayka.com.ua/?op=1\&z $=2204$ 